\title{
Fenugreek (Trigonellafoenum-graecum) and its Antimicrobial Activity - A Review
}

\author{
R. Yasmeen ${ }^{1 *}$ and J.N. Shashikumar ${ }^{2}$ \\ ${ }^{1}$ Department of Processing and Food Engineering, CAE, UAS Raichur, India \\ ${ }^{2}$ Department of Processing and Food Engineering, CTAE, MPUAT Udaipur -313001, India
}

*Corresponding author

\section{A B S T R A C T}

\section{Keywords \\ Fenugreek \\ (Trigonellafoenum- \\ graecum), \\ Antimicrobial \\ Activity \\ Article Info \\ Accepted: \\ 07 May 2019 \\ Available Online: \\ 10 June 2019}

\begin{abstract}
Fenugreek (Trigonellafoenum-graecum) is a legume and it has been used as a spice throughout the world to improve the sensory quality of foods. It is a medicinal plant that uses in disease some therapy. The plant contains active constituents such as alkaloids, flavonoids, steroids, Saponins etc. Fenugreek is known to have antidiabetic, anticarcinogenic, hypocholesterolemic, antioxidant, and immunological activities. Modern research has recognized fenugreek as a valuable medicinal plant with potential for curing diseases and also as a source for preparing raw materials of pharmaceutical industry, like in steroidal hormones. Use of fenugreek has been found to be lethal against hazardous bacteria, specifically coli forms, Pseudomonas spp., Shigella dysentiriae and Salmonella typhi. These properties probably make fenugreek a valuable ingredient in food and pharmaceutical applications.
\end{abstract}

\section{Introduction}

Fenugreek (Trigonella foenumgraecum) is self-pollinated an annual plant belongs to the family Leguminosae. It was called as "Trigonella" from Latin language that means "Little triangle" due to its yellowish-white triangular flower (Flammang et al., 2004) and species name "Foenum-graecum" means "Greek hay" indicating its use as a forage crop in the past. Fenugreek have originated in the Mediterranean region of the parts of Asia and newly it was suggested so as to fenugreek originated in Turkey. Fenugreek is famous all over the world. About 260 species are currently available in Trigonella genus. Most of the species include Trigonella foenumgraecum $\mathrm{L}$. are diploids with $2 \mathrm{n}=16$ chromosomes but some other species may include 18, 30, 32 or 44, 99 chromosomes (Acharya et al., 2014).

Fenugreek has been used both as a herb (the leaves) and as a spice (the seed) and also used to increase the flavor, colour and texture of the food materials, these days it is used as food stabilizer, adhesive and emulsifying agent due to its high fiber, protein and gum 
content (Meghwal and Goswami, 2012). Seed of fenugreek contain a substantial amount of phospholipids, glycolipids, oleic acid, linolenic acid, linoleic acid (Sulieman et al., 2000; Chatterjee et al., 2010), choline, vitamin A, B1, B2, C, nicotinic acid, niacin (Leela and Shafeekh, 2008), and many other functional elements. It also has some medicinal properties such as antioxidant, anticancer, antidiabetic, lactation aid, hypocholesterolemic, antimicrobial, gastric simulant for anorexia and hepatoprotective (Srinivasan, 2006).

\section{Chemical constituents of fenugreek (Trigonellafoenum-graecum)}

Fenugreek has been referred to as a medicinal herb both in Indian ayurvedic and traditional Chinese medicines (Tiran 2003). It contains a number of chemical constituents protein, starch, neutral detergent fiber, ash and lipids (Gupta et al., 1998).Generally, three important chemical constituents of fenugreek are very important; i.e. 1) steroidal sapogenins; 2) galactomannans and 3) isoleucine. These constituents have placed fenugreek among the most commonly recognized "nutraceutical" or health food products (Srichamroen et al., 2008). Three main constituents of fenugreek are saponins, flavonoids and alkaloids. The bitter taste and specific smell of fenugreek is due to alkaloids and some other volatile compounds (Altuntas et al., 2005).

\section{Fiber}

The fiber content of fenugreek seed extract plays a role in its ability to moderate metabolism of glucose in the digestive tract. Fenugreek can be used as source of natural antioxidants because of the fiber content (Raju et al., 2001). The $100 \mathrm{~g}$ of seeds gives more than $65 \%$ of dietary fibers. Dietary fiber of fenugreek can exert short term beneficial effects by reducing energy intake and increasing satiety as per one of the study conducted on obese people. It was reported that fiber of the fenugreek binds to cancer causing toxins of the intestine and removes them; it also lowers the rate of glucose absorption and helps in controlling blood sugar level (Meghwal and Goswami, 2012).

\section{Protein}

Fenugreek endosperm is highly rich in protein such as globulin, albumin, histidine and lecithin. Seed of fenugreek has a high proportion of protein ranging from 20 to $30 \%$ as well as amino acid, 4-hydroxyisoleucine, which contains high potential for insulinstimulating activity (Isikli and Karababa, 2005). Fenugreek proteins are stable enough, and are not affected during booking. Moreover, debitterized fenugreek seeds are rich in protein and lysine contents (Srinivasan, 2006).

\section{Vitamins and Minerals}

Fenugreek seed is a rich source of vitamins viz. vitamin A $(3 \mathrm{ug} / 100 \mathrm{~g}), \quad$ B1 $\quad(0.43$ $\mathrm{mg} / 100 \mathrm{~g}), \quad$ B2 $\quad(0.36 \mathrm{mg} / 100 \mathrm{~g}), \quad \mathrm{C} \quad(12-43$ $\mathrm{Mg} / 100 \mathrm{~g})$, nicotinic acid $(1.1 \mathrm{Mg} / 100 \mathrm{~g})$ and niacin $(6 \mathrm{mg} / 100 \mathrm{~g})$. Its leaves also contain vitamins, but on boiling, steaming or frying, $7-11 \%$ of them may be lost. Fenugreek seeds contain of potassium $(603.0 \mathrm{mg} / 100 \mathrm{~g})$, magnesium (42.0 mg/100g), calcium (75.0 $\mathrm{mg} / 100 \mathrm{~g})$, Zinc $(2.4 \mathrm{mg} / 100 \mathrm{~g})$ and iron $(25.8$ $\mathrm{mg} / 100 \mathrm{~g}$ ) (AlJasass and Al Jasass, 2012).

\section{Alkaloids, saponin and flavonoids in fenugreek (Trigonellafoenum-graecum)}

Fenugreek contains a fairly high amount of alkaloids, saponins and flavonoids. Alkaloids and volatiles are the two major constituents of fenugreek seed which causes bitter taste. Fenugreek endosperm contains $35 \%$ 
alkaloids, primarily trigonelline. Flavonoid constitutes more than $100 \mathrm{mg} / \mathrm{g}$ of fenugreek seed (Naidu et al., 2011). All these compounds are classified as biologically active as these have pharmacological effects on the human body when ingested. Their use should, therefore, be promoted in daily diet to manage hypercholesterolemia, cancer and diabetes mellitus as they possess hypoglycemic, antilipidemic, anticarcinogenic and cholagogic properties (Meghwal and Goswami, 2012).

\section{Antibacterial effect and Antifungal effect}

The antifungal activity of fenugreek was reported. Based on the studies carried out in fenugreek, worldwide report shows that the seeds of this plant possess strong antibacterial activity (Palombo and Semple, 2001). However very few reports are available on antibacterial properties of fenugreek seed against the important human pathogenic bacteria so far (Farrukh and Iqbal, 2003). In the present study we confirmed antimicrobial activity of fenugreek against pathogenic bacteria.

The antibacterial and antifungal role of fenugreek is recently being shown. In a study by Haouala et al., (2008), an aqueous extracts from various plant parts of fenugreek in various solvents include methanol, petroleum ether and ethyl acetate fractions of the aerial parts and determine their action against fungal strains such as Fusarium graminearum, Botrytis cinerea, Alternaria sp., Rhizoctonia solani and Pythium aphanidermatum.

The effectiveness of extracts obtained from fenugreek against Helicobacter pylori has been reported by several studies (O'Mahony et al., 2005; Randhir et al., 2004; Randhir and Shetty, 2007).

In a study, honey samples with highest antibacterial activity against Staphylococcus aureus, Pseudomonas aeruginosa and Escherichia coli show maximum pollens from fenugreek than other plants (Mercan et al., 2007). Cysteine-rich peptides, defensins are small with potent antifungal activity. The methanol soluble fraction of fenugreek extract showed nematicidal activity and caused significant mortality of Meloidogy nejavanica larvae, indicating the potential use against nematodes (Zia et al., 2001).

The antibacterial activity of Fenugreek's leaves, seeds and stem in aqueous, methanol and acetone extract against $E$. coli and Staphylococcus isolated from to be spoiled cabbage which is mostly available at very low cost and widely used by the local street food corners. In further study Methanol extract exhibit the highest zone of inhibition as compared to the aqueous extract. In comparison of all the extracts the leaves extracts was found to be maximum as compare to the extracts of seeds and stems. The results were obtained during this experiment were highly effective and comparable with the commercial antibiotic at $100 \mu$ concentration of Fenugreek extract (Sharma et al., 2017).

In conclusion, the active chemical compounds present in fenugreek should certainly find place in treatment of various bacterial infections. The results from the present study are very encouraging and indicate this herb should be studied more extensively to explore its potential in the treatment of many infectious diseases.

\section{References}

Acharya SN, Thomas JE, Basu SK. 2014. Fenugreek: an "old world" crop for the "new world". Biodiversity. 7:27-30.

Al Jasass FM and Al Jasser MS. 2012. Chemical composition and fatty acid content of some spices and herbs under Saudi Arabia conditions. Scientific 
World Journal. http://dx.doi.org/10. 1100/2012/859892.

Altuntas E, Ozgoz E and Taser OF. 2005. Some physical properties of fenugreek (Trigonella foenum-graceum L.) seeds. Journal of Food Engineering. 71:37-43.

Chatterjee S, Variyar PS and Sharma A. 2010. Bioactive lipid constituents of fenugreek. Food Chemistry. 1:349-353.

FarrukhAqil, and Iqbal Aharnad, 2003. Broad-spectrum antibacterial and antifungal properties of certain traditionally used Indian medicinal plants. World Journal of Microbiology and Biotechnology. 19: 653-657.

Flammang A, Cifone M, Erexson G, Stankowski L. 2004. Genotoxicity testing of a fenugreek extract. Food Chemistry Toxicology. 11:1769-1775.

Gupta K, Kumar N and Dahiya DS. 1998. Changes in structural carbohydrates and minerals in developing fenugreek (Trigonellafoenum-graecum) leaves. International Journal of Tropical Agriculture. 16:221-227.

Haouala R, Hawala S, El-Ayeb A, Khanfir R and Boughanmi N. 2008. Aqueous and organic extracts of Trigonellafoenumgraecum L. inhibit the mycelia growth of fungi. Journal of Environmental Science. 20:1453-1457.

Isikli ND and Karababa E. 2005.Rheological characterization of fenugreek paste (cemen), Journal of Food Engineering. 69:185-190.

Leela N and Shafeekh K. 2008. Fenugreek, Chemistry of Spices. CAB International, Pondicherry India.

Meghwal M, Goswami TK. 2012.A review on the functional properties, nutritional content, medicinal utilization and potential application of fenugreek. Journal of Food Process Technology. 3: 9.

Mercan N, Guvensen A, Celik A and Katircioglu H. 2007. Antimicrobial activity and pollen composition of honey samples collected from different provinces in Turkey. Natural Product Research. 21: 187-195.

Naidu MM, Shyamala B, Naik JP, Sulochanamma G and Srinivas P. 2011. Chemical composition and antioxidant activity of the husk and endosperm of fenugreek seeds. LWT - Food Science and Technology. 2:451-456.

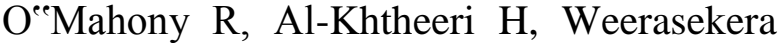
D, Fernando N, Vaira D, Holton, J and Basset C. 2005. Bactericidal and antiadhesive properties of culinary and medicinal plants against Helicobacter pylori. World Journal Gastroenterol. 11:7499-7507.

Palombo, E.A. and Semple, S.J. 2001. Antibacterial activity of traditional medicinal plants. Journal of Ethno pharmacology. 77: 151-157.

Raju J, Gupta D, Rao AR, Yadava PK and Baquer NZ. 2001. Trigonellafoenumgraecum (fenugreek) seed powder improves glucose homeostasis in alloxan diabetic rat tissues by reversing the altered glycolytic, gluconeogenic and lipogenic enzymes, Molecular and Cell Biochemistry. 224:45-51.

Randhir R and Shetty K. 2007. Improved alpha-amylase and Helicobacter pylori inhibition by fenugreek extracts derived via solid state bioconversion using Rhizopus oligosporus. Asia Pacific Journal of Clinical Nutrition. 16:382392.

Randhir R, Lin, YT and Shetty K. 2004.Phenolics their antioxidant and antimicrobial activity in dark germinated fenugreek sprouts in response to peptide and phytochemical elicitors. Asia Pacific Journal of Clinical Nutrition. 13: 295-307.

Sharma V, Singh P and Rani A. 2016. Antimicrobial activity of Trigonellafoenum-graecum L. 
(Fenugreek). European Journal of Experimental Biology. 7:1-4

Srichamroen A, Field CJ, Thomson AB andBasu TK. 2008. The modifying effects of galactomannan from Canadian grown fenugreek (Trigonellafoenum-graecum L.) on the glycemic and lipidemic status in rats. Journal of Clinical Biochemistry and Nutrition. 43(3): 167-74.

Srinivasan K. 2006. Fenugreek (Trigonellafoenum-graecum): A review of health beneficial physiological effects. Food Reviews International. 22(2): 203-224.
Sulieman AME, Ali AO, and Hemavathy J. 2000. Lipid content and fatty acid composition of fenugreek (Trogonellafoenum graceum L.) seeds grown in Sudan. International Journal of Food Science and Technology.43:380382.

Tiran D. 2003. The use of fenugreek for breast feeding women complement. The Nurse Midwifery. 9:155-156.

Zia T, Hasnain SN and Hasan SK. 2001. Evaluation of the oral hypoglycaemic effect of Trigonellafoenum-graecum L. (methi) in normal mice. Journal of Ethnopharmacol. 75:191-195.

\section{How to cite this article:}

Yasmeen, R. and Shashikumar, J.N. 2019. Fenugreek (Trigonellafoenum-graecum) and its Antimicrobial Activity- A Review. Int.J.Curr.Microbiol.App.Sci. 8(06): 710-714. doi: https://doi.org/10.20546/ijcmas.2019.806.083 